\title{
Cost-effectiveness of positron emission tomography for the management of potentially operable non-small cell lung cancer in Quebec
}

\author{
Van Hung Nguyen $\mathrm{MSc}^{1}$, Serge Péloquin $\mathrm{BSc}^{2}$, Yves Lacasse MD MSc FRCP ${ }^{3}$
}

VH Nguyen, S Péloquin, Y Lacasse. Cost-effectiveness of positron emission tomography for the management of potentially operable non-small cell lung cancer in Quebec. Can Respir J 2005;12(1):19-25.

BACKGROUND: The potential benefits of positron emission tomography (PET) scanning stem from the fact that it can reduce the number of diagnostic examinations; particularly, the number of unnecessary thoracic surgeries.

OBJECTIVE: To evaluate the economic impact and cost-effectiveness of PET scanning in the management of potentially operable nonsmall cell lung cancer in Quebec.

METHODS: A decision tree was developed. Two strategies were compared: chest computed tomography (CT) alone or CT and whole-body PET. The various paths of each strategy were dependent on the numerous variables that were determined from a literature review. The costs and life expectancy were determined for each strategy under consideration. Life expectancy was calculated using the declining exponential approximation of life expectancy. Costs were obtained from the Quebec diagnosis-related group database and Quebec physician fee schedules.

RESULTS: The mean cost of the CT strategy was $\$ 8,455$ per patient compared with $\$ 9,723$ for the PET strategy, for a cost differential of $\$ 1,268$. The PET strategy extended life expectancy by slightly more than three months ( 0.27 years) compared with the survival of the CT strategy. The incremental cost-effectiveness ratio was $\$ 4,689$. Considering the number of new cases and the prevalence of mediastinal metastases, the budget impact would be $\$ 8,613,693$.

CONCLUSION: The use of PET to detect local and distant metastases in non-small cell lung cancer is an intervention that would require an acceptable investment for each life-year gained.

Key Words: Cost-effectiveness; Lung cancer; Positron emission tomography

$\mathrm{R}$ ecent epidemiological data clearly show that lung cancer is Ra major public health problem in Quebec (1). Accounting for $30 \%$ of annual deaths, cancer is presently the second leading cause of mortality in Quebec, after cardiovascular diseases, which account for $37 \%$ of annual deaths (1). Given that the incidence of cancer increases with age, the relative importance of cancer in all deaths continues to increase because of the aging population (1). Statistics Canada forecasted that in 2003, 35,500 Quebecers of all ages would be diagnosed with some form of cancer, $18 \%$ with lung cancer and $15 \%$ with breast cancer (2). During the same year, 18,200 cancer deaths were expected

\section{Rapport coût-efficacité de la tomographie par émission de positrons dans le traitement du cancer du poumon non à petites cellules, virtuellement opérable, au Québec}

CONTEXTE : Les avantages possibles de la tomographie par émission de positrons (TEP) résident dans le fait que l'examen pourrait réduire le nombre d'autres examens de diagnostic, notamment d'interventions thoraciques non nécessaires.

BUT : L'étude avait pour but d'évaluer l'incidence économique et le rapport coût-efficacité de la TEP dans le traitement du cancer du poumon non à petites cellules, virtuellement opérable, au Québec.

MÉTHODE : Après avoir élaboré un arbre de décision, nous avons comparé deux démarches diagnostiques : la tomodensitométrie (TDM) seule de la cage thoracique et la TDM associée à la TEP du corps entier. Les différentes voies de chacune des démarches dépendaient des nombreuses variables relevées dans la documentation médicale. Nous avons déterminé, pour chacune des démarches à l'étude, les coûts et l'espérance de vie. L'espérance de vie a été calculée à l'aide de la diminution exponentielle approximative de l'espérance de vie; les coûts, eux, ont été obtenus à partir de la base de données du groupe lié au diagnostic au Québec et du barème d'honoraires établi pour les médecins au Québec.

RÉSULTATS : Le coût moyen de la TDM seule s'est établi à 8455 \$ par patient comparativement à 9723 \$ pour la TEP, ce qui fait un coût différentiel de 1268 \$. La TEP a permis une prolongation de l'espérance de vie légèrement supérieure à trois mois $(0,27$ an) par rapport à la survie associée à la TDM. Le rapport coût-efficacité différentiel a atteint 4689 \$. Compte tenu du nombre de nouveaux cas et de la prévalence des métastases médiastinales, l'intervention aurait une incidence de 8613693 \$ sur le budget.

CONCLUSION : Le recours à la TEP pour détecter la présence de métastases à proximité ou à distance d'un cancer primitif du poumon non à petites cellules est une intervention qui exigerait un investissement acceptable pour chaque année de vie gagnée.

to occur in Quebec. Thirty-two per cent of those deaths would occur due to lung cancer, which is both the most frequent and most fatal form of cancer.

Currently, the investigation of a patient suspected of having lung cancer is based on so-called 'conventional' diagnostic tools. Most often, these tools are used in a sequential fashion to make a diagnosis of cancer and to determine the extent of the disease. A chest $\mathrm{x}$-ray is usually the initial step for detecting the presence of a pulmonary lesion (nodule or mass), which always warrants further examination when it raises the suspicion of lung cancer. Bronchoscopy and transthoracic needle

\footnotetext{
${ }^{1}$ Agence d'évaluation des technologies et des modes d'intervention en santé, Montreal; ${ }^{2}$ Départment du développement et d'évaluation des technologies, Ministère de la santé et services sociaux, Quebec City; ${ }^{3}$ Centre de recherche, Centre de pneumologie, Hôpital Laval, Institut universitaire de cardiologie et de pneumologie de l'Université Laval, Ste-Foy, Quebec
}

Correspondence: Dr Yves Lacasse, Centre de Pneumologie, Hôpital Laval, 2725 Chemin Ste-Foy, Ste-Foy, Quebec G1V 4 G5. Telephone 418-656-4747, fax 418-656-4762, e-mail Yves.Lacasse@med.ulaval.ca 


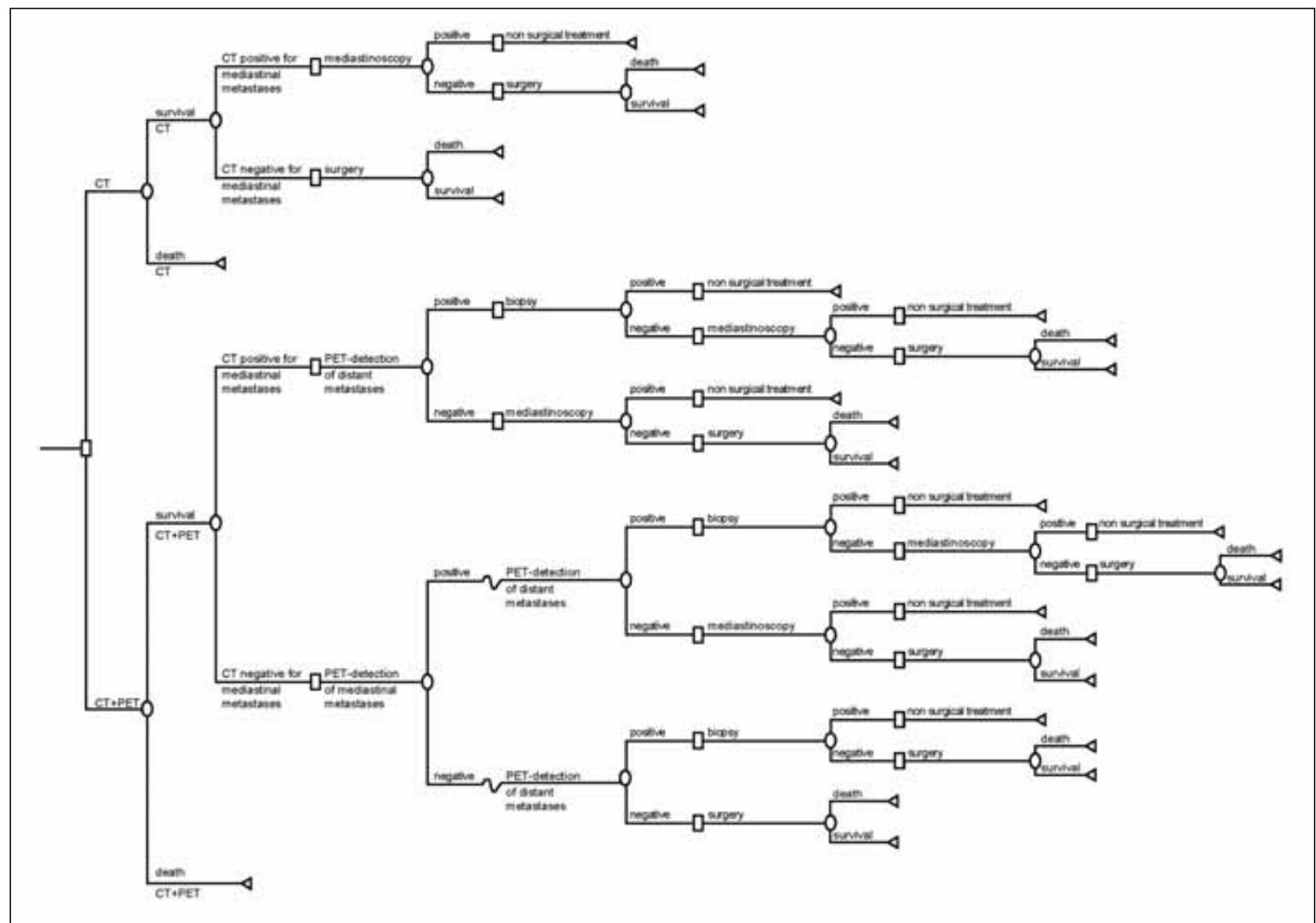

Figure 1) A schematic representation of the decision tree for the intervention strategies. CT Computed tomography; PET Positron emission tomography

biopsy are the tools used most often to determine the exact nature of the pulmonary lesion because they allow a sample of the pulmonary lesion to be taken. When indicated, a computed tomography (CT) scan of the chest, a bone scan, an abdominal ultrasound and a mediastinoscopy may be performed to determine the extent of the disease, eg, the presence or absence of mediastinal lymph node invasion by the cancer or the presence of distant metastases (3). The extent of the disease should be documented in each case because it determines both the best treatment modality to be used and the prognosis for the patient. The order in which these examinations should be performed and their utility is still debated.

Introduced as a research tool in the mid-1970s, positron emission tomography (PET) differs from other medical imaging technologies in that it enables the study of the metabolic activity and blood flow in tissues. At present, there is abundant literature supporting the utility of PET in diagnosing lung cancer and in detecting mediastinal and distant metastases. On the whole, these data show that PET is more sensitive and more specific than CT in diagnosing nodules and detecting lymph node metastases and distant metastases.

Several studies (4-7) have examined the economic aspect of PET when it is used to investigate solitary pulmonary nodules or confirmed lung cancer. Its potential benefits stem from the fact that it can reduce the number of diagnostic examinations; particularly, the number of unnecessary thoracic surgeries. The results of these studies suggest that PET, even when added to conventional examinations, is an efficient intervention.
In Quebec, it is unlikely that this technology will be used by clinicians as a diagnostic tool for solitary pulmonary nodules in the near future because of the limited access to it. Given that the prevalence of lung cancer in patients with a solitary pulmonary nodule varies from $80 \%$ to $90 \%$ when they are referred to a tertiary centre, the use of PET will probably be limited primarily to determining the stage of metastasis to assess the usefulness of undertaking surgical treatment.

It was in light of these specific considerations that an analysis based on the parameters of the province of Quebec was performed to assess the health and economic impact of PET and, thus, the usefulness of performing this technology in the context of clinical utilization. Presently, there are two PET centres in Quebec, but these facilities are mainly research-oriented.

\section{MATERIALS AND METHODS}

A decision tree was constructed for predicting the cost and effects of using PET as a means of detecting mediastinal and distant metastases. The study population consisted of a hypothetical cohort of medically fit-for-surgery 65-year-old men with histologically confirmed non-small cell lung cancer (NSCLC) in whom preoperative staging using conventional detection techniques was negative for mediastinal and distant metastases (3).

Thus, two intervention strategies were compared: CT and CT with PET (Figure 1). In the CT option, a mediastinoscopy was performed in patients with a positive result for mediastinal 
TABLE 1

List of the variables used

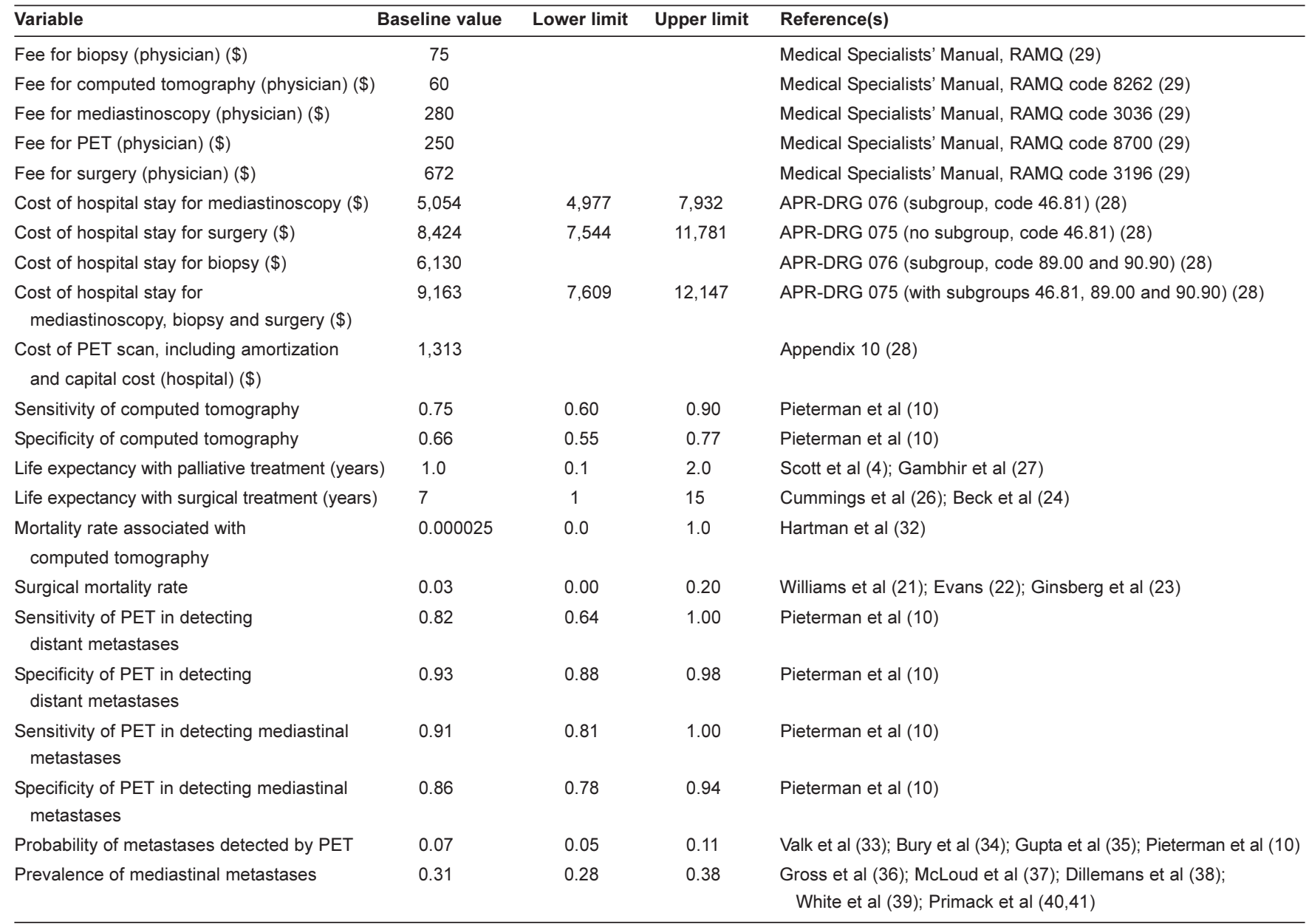

APR-DRG All Patient Refined Diagnosis Related Groups; PET Positron emission tomography; RAMQ Régie de l'Assurance Maladie du Québec

metastases to determine whether they would be candidates for surgery. In those cases where the CT results were negative, patients underwent surgery (8). As for the CT with PET option, all patients were first evaluated by CT. The use of PET was limited to detecting distant metastases when the CT findings were positive for mediastinal metastases and to detecting mediastinal metastases when the CT findings were negative. In the latter case, PET was also used to detect distant metastases. To confirm the PET results, a biopsy and mediastinoscopy were performed to determine if there were any distant or mediastinal metastases, respectively.

Although approximately $20 \%$ of patients with mediastinal metastases (mediastionoscopy-proven N2 disease) are amenable to surgery (9), the authors did not get into the details of induction chemotherapy and considered all patients with N2 disease to be unresectable.

The costs and life expectancy were determined for each strategy under consideration. Bayes' theorem was used to extract the majority of the probabilities.

\section{Construction of a decision tree}

A literature review was carried out to determine the adequacy of the available data on the sensitivity and specificity of PET and CT as means of detecting mediastinal and distant metastases and to gather the basic data for the model. A complete MEDLINE and
Cancerlit search was conducted for studies from 1999 to February 2001.

Table 1 shows the baseline values, the intervals that were used in the sensitivity analyses and the other variables used in the present analysis. The sensitivity of PET in detecting mediastinal metastases is estimated to be between $72 \%$ and $96 \%$, and between $90 \%$ and $100 \%$ for its specificity (10-20). As for its sensitivity and specificity in detecting distant metastases, Pieterman et al (10) estimated its sensitivity to be $82 \%$ (range $64 \%$ to $100 \%$ ) and its specificity to be $93 \%$ (range $88 \%$ to $98 \%$ ). For analytical purposes, the Pieterman et al study (10) was used as the main source of data for PET and CT sensitivity and specificity values because it was the only prospective study that estimated the performance of PET and CT in detecting mediastinal and distant metastases.

The mortality rates associated with the surgical resection of lung cancer that are reported in the literature vary enormously $(21,22)$. The data reported by Ginsberg et al $(23)$ were used for the general and specific mortality associated with thoracotomy. The life expectancy was calculated according to the Declining Exponential Approximation of Life Expectancy (DEALE method, which was developed by Beck et al (24), where:

$$
\text { Mean life expectancy }=1 /(A S R+D S R)
$$

and where the ASR is the age-, sex- and race-adjusted annual mortality rate in the general population and the DSR is the disease-related 
survival rate. In Quebec, the life expectancy of a 65-year-old man is 15.64 years (25). Thus, the ASR is $0.064(1 / 15.64)$. The DSR for a $2.3 \mathrm{~cm}$ lung tumour is 0.075 (26). Thus, the combined mortality rate for a typical patient is 0.139 .

The life expectancy for nonoperable cancers in patients with an advanced stage of the disease, based on radiographical findings, is estimated to be 0.47 years $(4,27)$. Although there is certainly survival data for patients with mediastinal metastases that are not detected radiographically, these patients probably exhibit better survival than those in whom the chest $\mathrm{x}$-ray was unequivocal. To take this factor into account, a life expectancy of one year (range 0.1 to 2 years) was the the baseline value for inoperable patients.

The cost of a PET scan was estimated from the costs of PET scanning at the Centre Hospitalier Universitaire de Sherbrooke in Sherbrooke, Quebec (François Bénard, written communication), which are shown in Table 2. The amortization of PET was estimated on the basis of the following assumptions. A scanner costs $\$ 3.2$ million, a cyclotron costs $\$ 4.3$ million, and the construction costs for a cyclotron and a scanner are $\$ 500,000$ and $\$ 175,000$, respectively. The life span of a scanner and that of a cyclotron were set at 10 years and 25 years, respectively. Finally, a $5 \%$ interest rate was used for amortization.

TABLE 2

Operating costs (cyclotron and positron emission tomography) for 1500 scans at Centre Hospitalier Universitaire de Sherbrooke

\begin{tabular}{ll}
\hline Item & Cost (\$) \\
\hline Salaries and employee benefits & 342,662 \\
Equipment and supplies & 169,800 \\
Maintenance contracts and costs & 360,000 \\
Grand total & 872,462 \\
\hline
\end{tabular}

The cost of a hospital stay for surgery alone, mediastinoscopy alone, biopsy alone and for all four interventions together was determined by consulting the Ministère de la Santé et des Services sociaux's 1998-1999 diagnosis-related group database (28). The figures for the physicians' fees are from the Medical Specialists' Manual (September 1999 edition) (29), published by the Régie de l'assurance-maladie du Québec, and are provided in Table 1 for each intervention. Lastly, the cost of a biopsy depends on its site and the technique performed. It can vary considerably. Therefore an average cost of $\$ 7$ was assumed.

The costs associated with the treatments required for this disease, such as chemotherapy and radiation therapy, were not included in the present analysis. In fact, it was assumed that a patient in whom surgical intervention would be avoided because of PET scanning would incur the same chemotherapy and radiation therapy costs as a patient who, before surgery, had metastases that were not detected by conventional diagnostic methods.

\section{Analysis}

A health care system perspective was adopted in the present analysis. Only the direct costs were considered. The incremental cost-effectiveness ratio (cost of the CT option - cost of the PET option)/(CT life expectancy - PET life expectancy) was used for the appraisal of PET efficiency. To test the robustness of the model, univariate sensitivity and Monte Carlo analyses were performed. The variables, intervals and predefined variable distributions for the Monte Carlo analysis are shown in Table 3. Lastly, given that the time horizon for the analysis is one year, no discounting of the costs or effects was necessary.

\section{RESULTS}

Table 4 shows the results per patient and the costs, efficacy, mean cost-effectiveness ratios and the incremental costeffectiveness ratio. The incremental cost-effectiveness ratio, ie, the cost associated with one additional life-year gained, was $\$ 4,689$. Considering the number of new cases and the prevalence of mediastinal metastases, 1837 new patients a year could

TABLE 3

Variables, intervals and predefined distributions for the Monte Carlo analysis

\begin{tabular}{|c|c|c|c|c|}
\hline Variable & Baseline value & Lower limit & Upper limit & Distribution \\
\hline Cost of hospital stay for mediastinoscopy $(\$)$ & 5,054 & 4,549 & 5,559 & Normal, $20 \%$ variance \\
\hline Cost of surgery $(\$)$ & 8,424 & 7,582 & 9,266 & Normal, $20 \%$ variance \\
\hline Cost of hospital stay for biopsy (\$) & 6,130 & 5,517 & 6,743 & Normal, $20 \%$ variance \\
\hline $\begin{array}{l}\text { Cost of hospital stay for mediastinoscopy, } \\
\text { biopsy and surgery (\$) }\end{array}$ & 9,163 & 8,247 & 10,079 & Normal, $20 \%$ variance \\
\hline Sensitivity of computed tomography & 0.75 & 0.60 & 0.90 & Triangular \\
\hline Specificity of computed tomography & 0.66 & 0.55 & 0.77 & Triangular \\
\hline $\begin{array}{l}\text { Life expectancy of patients who receive } \\
\text { palliative treatment }(\$)\end{array}$ & 1.0 & 0.1 & 2.0 & Uniform \\
\hline $\begin{array}{l}\text { Life expectancy of patients who are } \\
\text { treated surgically (years) }\end{array}$ & 7 & 1 & 15 & Uniform \\
\hline Surgical mortality rate & 0.03 & 0.02 & 0.20 & Uniform \\
\hline Sensitivity of PET in detecting distant metastases & 0.82 & 0.64 & 1.00 & Triangular \\
\hline Specificity of PET in detecting distant metastases & 0.93 & 0.88 & 0.98 & Triangular \\
\hline Sensitivity of PET in detecting mediastinal metastases & 0.91 & 0.81 & 1.00 & Triangular \\
\hline Specificity of PET in detecting mediastinal metastases & 0.86 & 0.78 & 0.94 & Triangular \\
\hline Probability of metastases detected by PET & 0.07 & 0.05 & 0.11 & Uniform \\
\hline Prevalence & 0.31 & 0.28 & 0.38 & Uniform \\
\hline
\end{tabular}

PET Positron emission tomography 
TABLE 4

Results for each strategy per patient (lung cancer)

\begin{tabular}{|c|c|c|c|c|c|c|}
\hline Strategy & Cost (\$) & $\begin{array}{l}\text { Incremental } \\
\text { cost }(\$)\end{array}$ & $\begin{array}{c}\text { Efficacy } \\
\text { (life-years) }\end{array}$ & $\begin{array}{c}\text { Incremental } \\
\text { efficacy }\end{array}$ & $\begin{array}{c}\text { Mean cost- } \\
\text { effectiveness ratio }\end{array}$ & $\begin{array}{l}\text { Incremental cost-effectiveness ratio } \\
\text { ( } \$ \text { per additional life-year gained) }\end{array}$ \\
\hline Computed tomography & 8,455 & & 4551 & & $\$ 1,858$ per life-year & \\
\hline Computed tomography + PET & 9,723 & 1,268 & 4823 & 0.27 & $\$ 2,017$ per life-year & 4,689 \\
\hline
\end{tabular}

PET Positron emission tomography

TABLE 5

Results of the univariate sensitivity analysis

\begin{tabular}{|c|c|c|}
\hline & & $\begin{array}{l}\text { Incremental cost- } \\
\text { effectiveness ratio } \\
\text { (\$ per life-year gained) }\end{array}$ \\
\hline Baseline scenario & & 4,689 \\
\hline Surgical mortality rate & 0.02 to 0.1 & 4,765 to 4,997 \\
\hline Prevalence & 0.15 to 0.5 & 4,925 to 5,358 \\
\hline Cost of stay for surgery alone $(\$)$ & 7,544 to 11,781 & 15,376 to 2,841 \\
\hline $\begin{array}{l}\text { Cost of stay for surgery and } \\
\text { mediastinoscopy (\$) }\end{array}$ & 7,609 to 12,147 & 4,489 to 5,073 \\
\hline Surgical mortality rate & 0 to 0.2 & 4,599 to 5,277 \\
\hline $\begin{array}{l}\text { Life expectancy of patients who } \\
\text { receive palliative treatment (years) }\end{array}$ & 0.1 to 2.0 & 4,118 to 5,542 \\
\hline $\begin{array}{l}\text { Life expectancy of patients who } \\
\text { are treated surgically (years) }\end{array}$ & 1 to 15 & 724,242 to 1,324 \\
\hline $\begin{array}{l}\text { Specificity of PET in detecting } \\
\text { mediastinal metastases }\end{array}$ & 0.65 to 0.85 & 7,080 to 7,156 \\
\hline $\begin{array}{l}\text { Sensitivity of PET in detecting } \\
\text { distant metastases }\end{array}$ & 0.64 to 1.00 & 3,145 to 3,019 \\
\hline $\begin{array}{l}\text { Specificity of PET in detecting } \\
\text { distant metatases }\end{array}$ & 0.73 to 1.00 & 3,226 to 3,032 \\
\hline $\begin{array}{l}\text { Probability of distant metastases } \\
\text { detected by PET }\end{array}$ & 0.05 to 0.11 & 2,660 to 4,689 \\
\hline
\end{tabular}

PET Positron emission tomography

potentially benefit from this technology. The budget impact, from the perspective of the incremental cost, ie, the additional cost to the health care system, would be $\$ 8,613,693$. If the same analysis was performed after excluding amortization from the cost of PET scanning, the incremental costeffectiveness ratio would be $\$ 1,983$, with a budget impact of $\$ 3,642,771$.

The results of the univariate sensitivity analysis are shown in Table 5 for all the variables included in the model. The variation in the baseline values did not have an impact on the decision: the mean cost-effectiveness ratio for the PET strategy was always higher than the competing option.

The Monte Carlo simulation is presented in Figure 2. Most of the results of the simulations were in the right quadrant, the quadrant where the PET option would improve life expectancy while requiring an investment for each additional health gain at the same time. Table 6 shows the mean, median and quartiles for the incremental cost, effectiveness and cost-effectiveness ratio values, as they appeared in the dynamic sensitivity analysis.

The frequencies of occurrence of the incremental costeffectiveness ratios, by intervals, of the 1000 Monte Carlo simulations are presented in Table 7. Thus, in 95\% of the cases, the incremental ratio was less than $\$ 50,000$ per life-year gained.

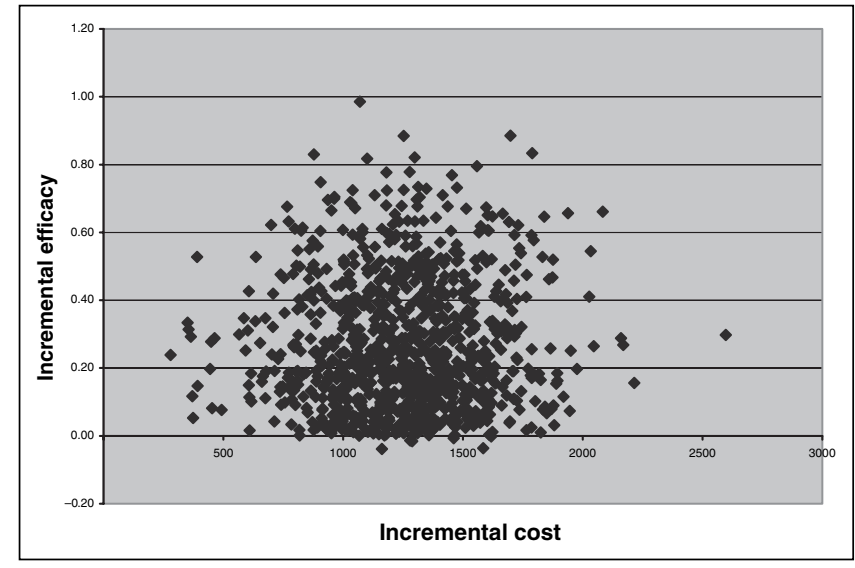

Figure 2) Monte Carlo analysis (1000 simulations). Each point on the graph represents the result of a simulation

TABLE 6

The mean, median and quartiles from the Monte Carlo analysis

\begin{tabular}{lcccc}
\hline & & $\begin{array}{c}\text { Incremental } \\
\text { cost (\$) }\end{array}$ & $\begin{array}{c}\text { Incremental } \\
\text { efficacy }\end{array}$ & $\begin{array}{c}\text { Incremental cost- } \\
\text { effectiveness ratio } \\
\text { (\$ per life-year gained) }\end{array}$ \\
\hline Mean & & 1,253 & 0.26 & 17,666 \\
Median & & 1,260 & 0.22 & 5,342 \\
Quartile & 25 & 1,052 & 0.12 & 3,006 \\
& 50 & 1,260 & 0.22 & 5,342 \\
& 75 & 1,442 & 0.39 & 10,618 \\
& 100 & 2,598 & 0.99 & $4,058,550$ \\
\hline
\end{tabular}

\section{DISCUSSION}

Our study suggests that PET is a cost-effective intervention in the specific context of its clinical use and deployment in Quebec if we define an intervention as cost-effective if its incremental ratio is under $\$ 50,000$ per life-year gained. Of note, the results are similar to those compiled by the Australian Medicare Services Advisory Committe (30), that PET can lead to savings or require only a very small and very acceptable investment for each life-year gained, provided the purchase costs, which are high, have been amortized.

Our univariate and Monte Carlo sensitivity analyses confirmed the robustness of the results. Varying the baseline values did not significantly affect the results: the incremental costeffectiveness ratio ranged from $\$ 3,000$ to $\$ 5,000$ per life-year gained. Moreover, in approximately $50 \%$ of the Monte Carlo simulations, the investment required to gain one life-year was less than $\$ 5,000$. In $73 \%$ of the cases, it was less than $\$ 10,000$, which was not, in itself, a very large investment. If the standard cost-effectiveness ratio was set at less than $\$ 50,000$ per 


\begin{tabular}{|c|c|}
\hline Interval (incremental cost-effectiveness ratio [\$]) & Percentage \\
\hline 0 to 4,999 & 46 \\
\hline 5,000 to 9,999 & 26 \\
\hline 10,000 to 14,999 & 9 \\
\hline 15,000 to 19,999 & 4 \\
\hline 20,000 to 24,999 & 3 \\
\hline 25,000 to 29,999 & 2 \\
\hline 30,000 to 34,999 & 2 \\
\hline 35,000 to 39,999 & 1 \\
\hline 40,000 to 44,999 & 1 \\
\hline 45,000 to 49,999 & 1 \\
\hline$>50,000$ & 5 \\
\hline Total & 100 \\
\hline
\end{tabular}

life-year gained, $95 \%$ of the simulation cases would be below this figure. Thus, economically, PET would not necessarily generate any savings in the health care system, but it might help to avoid unnecessary surgeries and therefore, to a certain extent, shorten the waiting lists and contribute to the overall efficiency of the health care system.

Using the available data, we attempted to assess the health and economic impact of PET on clinical outcomes and the health care system. Because there is no direct measure of patient survival, we used an intermediate measure, such as the reduction in the mortality due to surgical procedures. However, using such an indicator does not enable us to fully assess the utility of PET. In the short term, it is unlikely that PET would improve survival in patients with lung cancer per se. Instead, the efficacy of PET resides in its ability to improve patients' quality of life by sparing them an unnecessary, debilitating intervention and providing them with quicker access to treatment, on the one hand, and to enable them to express their preferences in terms of the clinical approach to be used.

\section{REFERENCES}

1. Bureau de la Statistique du Québec. D'une génération à l'autre : évolution des conditions de vie, volume 2, chapter 9. Quebec City: Publication du Québec, 1998.

2. Canadian Cancer Society, Quebec. Statistics.

$<$ http://www.cancer.ca/ccs/internet/standard/0,3182,3649_12851_la ngId-en,00.html > (Version current at December 14, 2004) and National Cancer Institute of Canada. Canadian Cancer Statistics. <http://www.ncic.cancer.ca/vgn/images/portal/cit_86751114/27/0/89 485729cancerstatistics2003_en.pdf> (Version current at December 14, 2004).

3. The American Thoracic Society and The European Respiratory Society. Pretreatment evaluation of non-small-cell lung cancer. Am J Respir Crit Care Med 1997;156:320-32.

4. Scott WJ, Shepherd J, Gambhir SS. Cost-effectiveness of FDG-PET for staging non-small cell lung cancer: A decision analysis. Ann Thorac Surg 1998;66:1876-85.

5. Gambhir SS, Shepherd JE, Shah BD, et al. Analytical decision model for the cost effective management of solitary pulmonary nodules. J Clin Oncol 1998;16:2113-25.

6. Dietlein M, Weber K, Gandjour A, et al. Cost-effectiveness of FDG-PET for the management of solitary pulmonary nodules: A decision analysis based on cost reimbursement in Germany. Eur J Nucl Med 2000;27:1441-56.
Quality of life and patient preference measurements obtained by prospective studies will permit a more adequate assessment of the efficacy of this technology.

We included the investment costs required to implement PET in Quebec. For analytical purposes, we considered a very cautious scenario and assumed that this technology would be used only to detect local and distant metastases in patients with NSCLC. Given this technology would be used for clinical purposes other than detecting metastases in patients with NSCLC, the amortization should not be done on the basis of this single application. Thus, the amortization to be included in the cost of PET scanning would probably be less than $\$ 732$ per use, which would significantly reduce the incremental cost-effectiveness ratio.

Because the analysis was limited to a single clinical use (the detection of metastases in cases of NSCLC) and to a very limited population, other studies are needed to confirm PET's efficiency or lack thereof in other applications. Our prediction model estimates the reduction in the number of surgeries at $12 \%$, with patient survival prolonged by three months. These figures are similar to the results of a randomized, prospective study (31) presented at the 2000 American Society of Clinical Oncology conference.

\section{CONCLUSIONS}

With the current state of knowledge and from an economic perspective specific to the situation in Quebec, our model shows that the use of PET to detect local and distant metastases in NSCLC is an intervention that would require an acceptable investment for each life-year gained.

ACKNOWLEDGEMENTS: The authors would like to thank Dr François Bénard, Head of the Department of nuclear medicine, Centre Hospitalier Universitaire de Sherbrooke, Sherbrooke, and Dr James A Hanley, Department of Epidemiology and Biostatistics, McGill University, Montreal, for their helpful comments in the preparation of this manuscript.

FUNDING: This study was supported by and originated from the the Agence d'évaluation des technologies et des modes d'intervention en santé (AETMIS).

7. Dietlein M, Weber K, Gandjour A, et al. Cost-effectiveness of FDG-PET for the management of potentially operable non-small cell lung cancer: Priority for a PET-based strategy after nodalnegative CT results. Eur J Nucl Med 2000;27:1598-609.

8. The Canadian Lung Oncology Group. Investigation for mediastinal disease in patients with apparently operable lung cancer. Ann Thorac Surg 1995;60:1382-9.

9. Pearson FG, DeLarue NC, Ilves R, Todd TR, Cooper JD. Significance of positive superior mediastinal nodes identified at mediastinoscopy in patients with respectable cancer of the lung. J Thorac Cardiovasc Surg 1982;83:1-11.

10. Pieterman RM, van Putten JWG, Meuzelaar JJ, et al. Preoperative staging of non-small-cell lung cancer with positron-emission tomography. N Engl J Med 2000;343:254-61.

11. Erasmus JJ, McAdams HP, Rossi SE, Goodman PC, Coleman RE, Patz EF. FDG PET of pleural effusions in patients with non-small cell lung cancer. AJR Am J Roentgenol 2000;175:245-9.

12. Gupta NC, Graeber GM, Bishop HA. Comparative efficacy of positron emission tomography with fluorodeoxyglucose in evaluation of small $(<1 \mathrm{~cm})$, intermediate $(1$ to $3 \mathrm{~cm})$, and large $(>3 \mathrm{~cm})$ lymph node lesions. Chest 2000;117:773-8.

13. Vanuytsel LJ, Vansteenkiste JF, Stroobants SG, et al. The impact of (18)F-fluoro-2-deoxy-D-glucose positron emission tomography 
(FDG-PET) lymph node staging on the radiation treatment volumes in patients with non-small cell lung cancer. Oncol 2000;55:317-24.

14. Marom EM, McAdams HP, Erasmus JJ, et al. Staging non-small cell lung cancer with whole-body PET. Radiology 1999;212:803-9.

15. Roberts PF, Follette DM, vonHaag D, et al. Factors associated with false-positive staging of lung cancer by positron emission tomography. Ann Thorac Surg 2000;70:1154-60.

16. Hara T, Inagaki K, Kosaka N, Morita T. Sensitive detection of mediastinal lymph node metastasis of lung cancer with 11C-choline PET. J Nucl Med 2000;41:1507-13.

17. Weber WA, Neverve J, Sklarek J, et al. Imaging of lung cancer with fluorine-18 fluorodeoxyglucose: Comparison of a dual-head gamma camera in coincidence mode with a full-ring positron emission tomography system. Eur J Nucl Med 1999;26:388-95.

18. Berlangieri SU, Scott AM, Knight SR, et al. F-18 fluorodeoxyglucose positron emission tomography in the non-invasive staging of non-small cell lung cancer. Eur J Cardiothoracic Surg 1999;16(Suppl 1):S25-30.

19. Saunders CA, Dussek JE, O’Doherty MJ, Maisey MN. Evaluation of fluorine-18-fluorodeoxyglucose whole body positron emission tomography imaging in the staging of lung cancer. Ann Thorac Surg 1999;67:790-7.

20. Magnani P, Carretta A, Rizzo G, et al. FDG/PET and spiral CT image fusion for medistinal lymph node assessment of non-small cell lung cancer patients. J Cardiovasc Surg (Torino) 1999;40:741-8.

21. Williams DE, Pairolero PC, Davis CS, et al. Survival of patients surgically treated for stage I lung cancer. J Thorac Cardiovasc Surg $1981 ; 82: 70-6$

22. Evans EW. Resection for bronchial carcinoma in the elderly. Thorax 1973;28:86-8.

23. Ginsberg RJ, Hill LD, Eagan RT, et al. Modern thirty-day operative mortality for surgical resections in lung cancer. J Thorac Cardiovasc Surg 1983;86:654-8.

24. Beck JR, Kassirer JP, Pauker SG. A convenient approximation of life expectancy (the "DEALE"). I. Validation of the method. Am J Med 1982;73:883-8.

25. Espérance de vie à la naissance et à 65 ans selon le sexe, Québec, 1980-1982 à 2001-2003. Institut de la Statistique du Québec 2001. <http://www.stat.gouv.qc.ca/donstat/societe/demographie/naisn_de ces $/ 4$ p1.htm $>$ (Version current at December 14, 2004).

26. Cummings SR, Lillington GA, Richard RJ. Estimating the probability of malignancy in solitary pulmonary nodules. A Bayesian approach. Am Rev Respir Dis 1986; 134:449-52.

27. Gambhir SS, Hoh CK, Phelps ME, Madar I, Maddahi J. Decision tree sensitivity analysis for cost-effectiveness of FDG-PET in the staging and management of non-small-cell lung carcinoma. J Nucl Med 1996;37:1428-36.
28. Fichier des hospitalisations MED-ÉCHO (APR-DRG). Ministère de la Santé et des Services Sociaux 1998-1999. Institut Canadien d'Information sur la Santé (ICIS).

29. Medical Specialist's Manual. Quebec: Régie de l'Assurance Maladie du Québec, 1999.

30. Positron Emission Tomography, March 2000. MSAC Assessment Report. Medical Services Advisory Committee. <http://www.msac.gov.au/pdfs/reports/msacref02.pdf> (Version current at December 14, 2004)

31. van Tinteren H, Hoekstra OS, Smit EF, et al. Effectiveness of positron emission tomography in the preoperative assessment of patients with suspected non-small cell lung cancer: The PLUS multicentre randomised trial. Lancet 2002;359:1388-93.

32. Hartman GW, Hattery RR, Written D, Williamson B Jr. Mortality during excretory urography. Mayo Clinic experience. AJR Am J Roentgenol 1982;139:919-22.

33. Valk PE, Pounds TR, Hopkins DM, et al. Staging non-small cell lung cancer by whole-body positron emission tomographic imaging. Ann Thorac Surg 1995;60:1573-82.

34. Bury T, Barreto A, Daenen F, Barthelemy N, Ghaye B, Rigo P. Fluorine-18 deoxyglucose positron emission tomography for the detection of bone metastases in patients with non-small cell lung cancer. Eur J Nucl Med 1998;25:1244-7.

35. Gupta NC, Graeber GM, Rogers JS II, Bishop HA. Comparative efficacy of positron emission tomography with FDG and computed tomographic scanning in preoperative staging of non-small cell lung cancer. Ann Surg 1999;229:286-91.

36. Gross BH, Glazer GM, Orringer MB, Spizarny DL, Flint A Bronchogenic carcinoma metastatic to normal-sized lymph nodes: Frequency and significance. Radiology 1988;166:71-4.

37. McLoud TC, Bourgouin PM, Greenberg RW, et al. Bronchogenic carcinoma: Analysis of staging in the mediastinum with CT by correlative lymph node mapping and sampling. Radiology 1992;182:319-23.

38. Dillemans B, Deneffe G, Verschakelen J, Decramer M. Value of computed tomography and mediastinoscopy in preoperative evaluation of mediastinal nodes in non-small cell lung cancer. A study of 569 patients. Eur J Cardiothorac Surg $1994 ; 8: 37-42$.

39. White PG, Adams H, Crane MD, Butchart EG. Preoperative staging of carcinoma of the bronchus: Can computed tomographic scanning reliably identify stage III tumours? Thorax 1994;49:941-3.

40. Primack SL, Lee KS, Logan PM, Miller RR, Muller NL. Bronchogenic carcinoma: Utility of CT in the evaluation of patients with suspected lesions. Radiology 1994;193:795-800.

41. Primack SL, Hartman TE, Lee KS, Muller NL. Pulmonary nodules and the CT halo sign. Radiology 1994;190:513-5. 


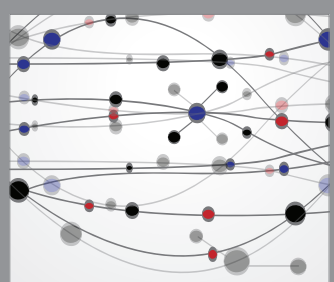

The Scientific World Journal
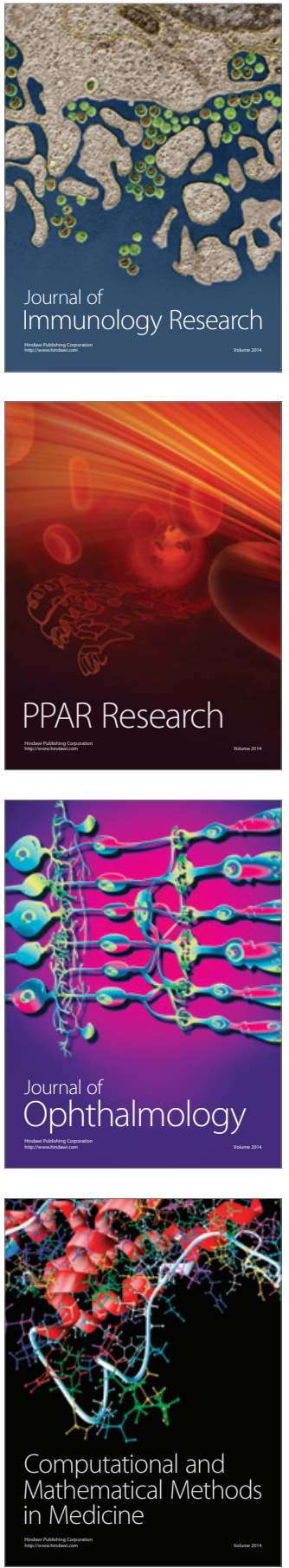

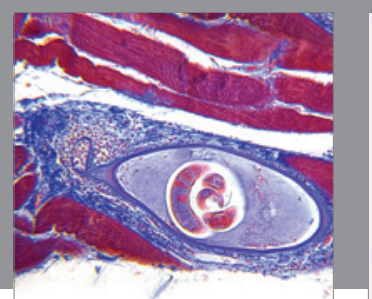

Gastroenterology Research and Practice

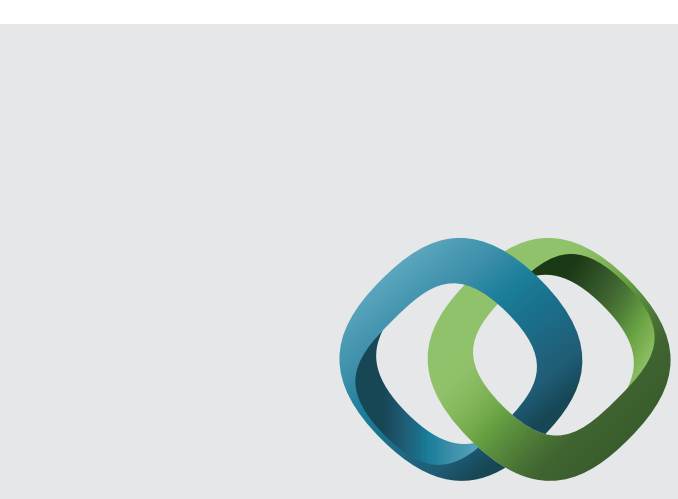

\section{Hindawi}

Submit your manuscripts at

http://www.hindawi.com
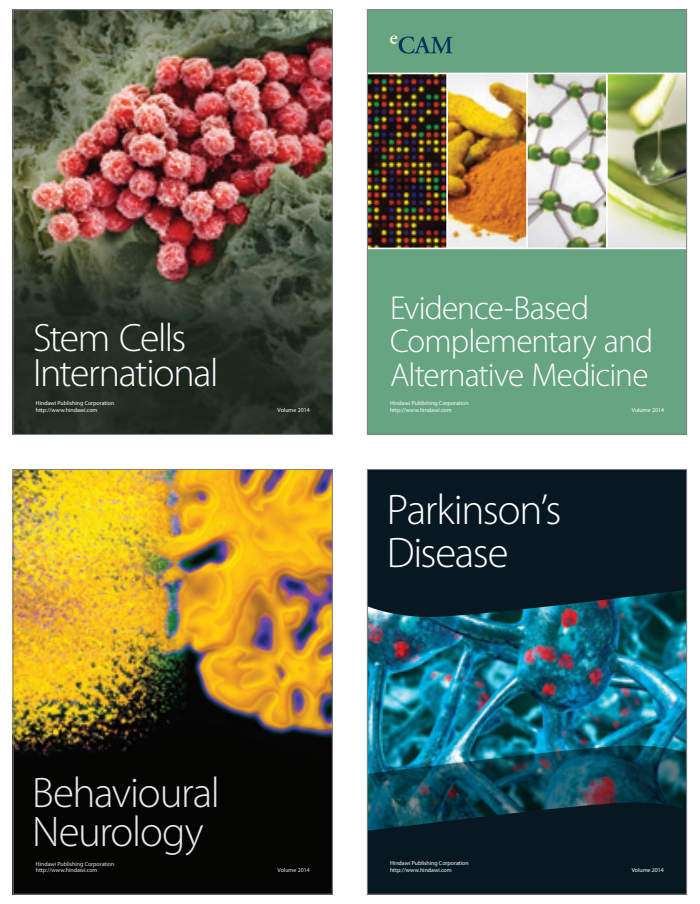
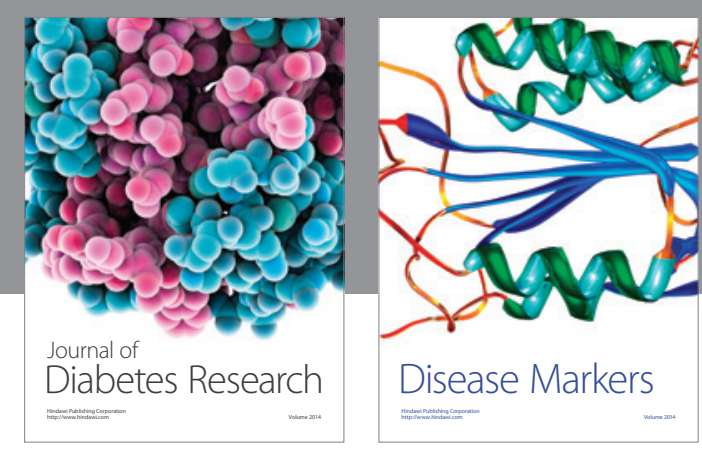

Disease Markers
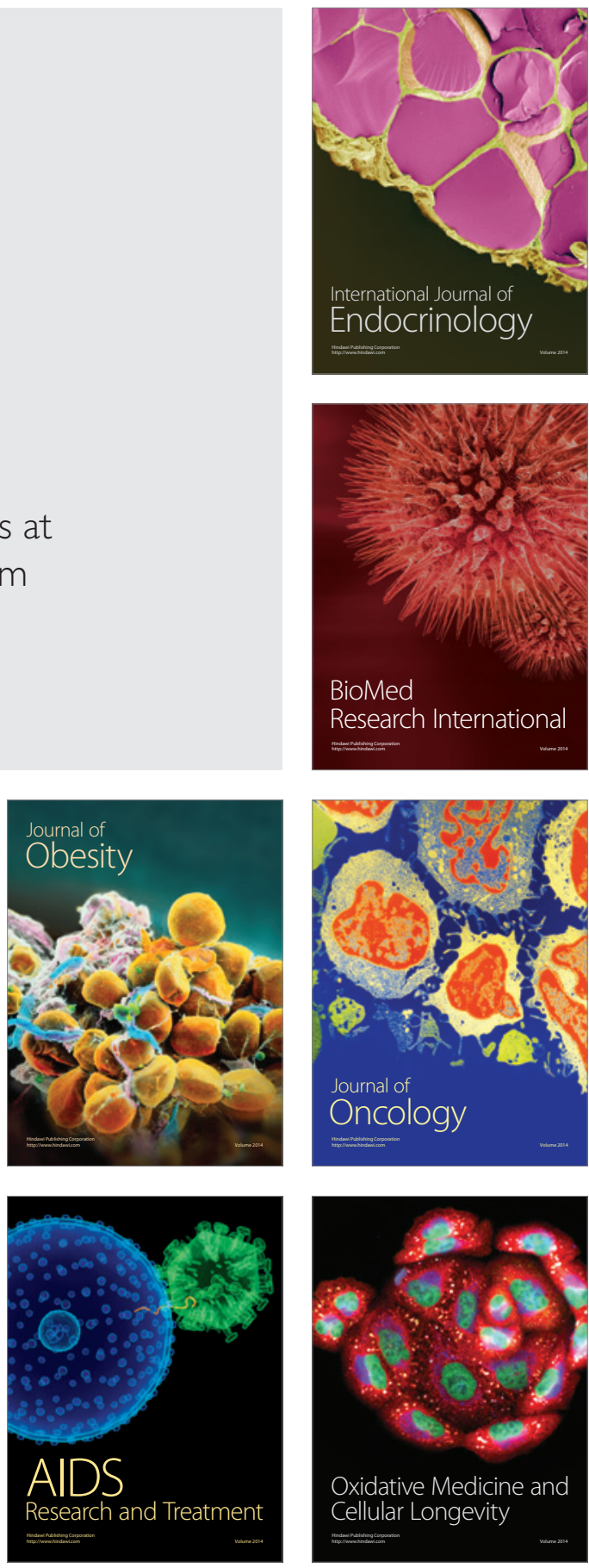